\title{
What We Know about the Impact of School and Scouting on Adolescents' Value-based Leadership
}

\section{Émiliane Rubat du Mérac}

Doctoral Student in Education (27th cycle) - Università degli Studi Roma Tre (Italy)

doi: 10.7358/ecps-2015-011-dume

emirubatdumerac@yahoo.com

\section{CIÒ CHE SAPPIAMO DELL'IMPATTO DELLA SCUOLA \\ E DELLO SCOUTISMO SULLA LEADERSHIP RESPONSABILE DEGLI ADOLESCENTI}

\begin{abstract}
The purpose of this study is to understand the impact of the school environment compared to the Scouting environment on the leadership attitudes of adolescents. The ways in which the social context affects the development of leadership attitudes is of special importance in view of the guidelines issued by the OECD, UNESCO and European Union, which envision schools as places of social development. In order to examine the ways in which these different contexts affect leadership development, we used two instruments: the "Educational Context Perception Questionnaire» (ECPQ), for the analysis of the adolescents' perception of their educational context, and the "Socially Responsible Leadership Scale» (SRLS), which measures the Individual, Group, and Social Values of the adolescents, to which we added a dimension of Leadership Capacities. The study was conducted on a judgment sample, consisting of 600 students and 231 Scouts enrolled in upper secondary school in Rome (9th and 10th grades). Path-analyses were conducted to test, for the students and the Scouts, the effects of the ECPQ dimensions on leadership attitudes and capacities and to determine the relationships between the leadership dimensions. Findings revealed different effects among students and Scouts, of the educational context perception on their leadership attitudes and capacities, an effect of the Individual Values on the Group Values and an effect of the Group Values on the Social Values and Leadership Capacities.
\end{abstract}

Keywords: Adolescent leadership development, Educational Context Perception Questionnaire (ECPQ), High School, Scouting, Social Change Model (SCM), Socially Responsible Leadership Scale (SRLS), Value-based Leadership. 


\section{INTRODUCTION AND RESEARCH OBJECTIVES}

The school environment's role in social development includes two elements that may seem contradictory. On the one hand, schools respond to young people's need for socialization and foster adaptation to rules and social practices (Hobbes, 1651; Durkheim, 1922; Parsons, 1951). On the other hand, schools aim to make students autonomous, responsible and able to contribute to the betterment of society (Dewey, 1897; Makarenko, 1933-1935; Bruner, 1961). Therefore, school should ensure both continuity and consistency, as well as discontinuity and self-governance. This research focuses on the second aspect of education. Learning autonomy and active participation requires interaction with the environment and with others, which are also necessary for developing leadership attitudes and capacities. As Loughran and Russell explained, «Experience precedes understanding», thus it is essential to create an environment that enables active participation and collaboration for learning how to practice a shared and responsible leadership (Loughran \& Russell, 1997). Learning and leadership aims can be productively joined together. As Woods notes "Learning in a democratic way aids the development of independent thinking and creativity, which in turn is fundamental to democracy» (Woods, 2005, p. 55).

Although the subject of leadership is much discussed in educational literature, the main reference concerns the training of school leaders (Bossert et al., 1982; Leithwood \& Montgomery, 1982; Glasman, 1984; Hallinger \& Murphy, 1985; Dwyer, 1986; Leithwood et al., 1990; van de Grift, 1990; Domenici \& Moretti, 2011). However, youth leadership receives little attention (Skinner et al., 2010).

In recent years, international organizations have encouraged and required the promotion of civic participation (OECD, 2012), leading to an increase in attempts to foster civic knowledge and to develop responsible citizenship attitudes in school environments (Schulz \& Sibberns, 2004; UNESCO, 2005). In Italy, for example, the Charter of student rights and responsibilities stresses the importance of encouraging active participation, a sense of responsibility, critical thinking skills and citizenship. However, the expectations placed on schools to improve leadership attitudes and life skills (WHO, 1993) are not accompanied by concrete suggestions for change. One of the aims of the present study is to better understand how school environment should be organized to effectively develop leadership and civic responsibility.

The research objective was to analyze the differences in terms of acquisition of leadership attitudes between 15-16 year olds in school and Scouting contexts, in order to measure the relationship between their development 
and the educational model. We analyzed how these adolescents perceived what happened in their classes or Scout groups to evaluate whether, and to what extent, these perceptions of some aspects of the educational context have an impact on their leadership attitudes.

Scouting was chosen as a comparative educational model for several reasons. First of all, it is a well-structured educational method that is spread worldwide and that uses an active learning approach in order to develop moral values and leadership attitudes in young people. The fundamental purpose of Scouting, in fact, is to foster the development of character and a sense of service, the acquisition of skills and self-confidence, and to develop the abilities to both cooperate and lead (WOSM, 2011). The founder of Scouting, Baden Powell, intended to offer an educational environment in which young people could learn through experience, that would enable them to try and get used to making decisions; these aims were in line with and drawn from active learning methods and the Montessori method. Furthermore, the comparison between Scouting and educational contexts allows us to understand to what extent the leadership attitudes of the 15-16 year olds could vary and to measure the impact of an educational context different from that of the school on these attitudes.

\section{RESEARCH CONTEXT}

In the Italian school system, the traditional disciplinary approach is still widely used. However, recent legislation on school autonomy, in force from 2000-2001, encourages the organization of school activities centered on active participation and student leadership.

The OECD report (2004) Learning for tomorrow's world insists that the school cannot restrict its mission only to the promotion of knowledge, but should also provide social and life skills training, with leadership being defined as an essential element of such training. UNESCO (2005) analyzes the quality of education through two indicators. The first relates to the student's cognitive development. The second indicator concerns the promotion of values and attitudes of citizenship, and conditions that promote emotional well-being and creativity.

The European Commission (2010), like the OECD, focuses its objectives on economic development, but also stresses the importance of education for active citizenship and for promoting democratic values. Among the key competencies outlined in the document Europe 2020 strategy for smart, sustainable and inclusive growth social skills, together with the sense of initiative 
and enterprise, are considered favorable to stimulate an active and positive participation of young people in social and professional life. However, Grace (1995) warns us that helping young people to become active and responsible citizens has to be a purpose, and not a means to achieve more effectively the goals dictated by economic competitiveness, since «Only forms of education more consciously designed to foster democratic values and behaviors can help to further democratic processes» (Harber, 2002).

\section{THEORETICAL FRAMEWORK}

The research is based on three main assumptions. The first is the idea that the educational process includes the transmission of values and moral models. As claimed by Bourdieu (1972) and Kohlberg (1984), teachers transmit a socialmoral point of view, as bearers of a "hidden curriculum», which pervades the moral atmosphere of the class. The second assumption is that people learn skills such as leadership in a context in which they have the opportunity to experience it. In the words of John Dewey (1916), «we never educate directly, but indirectly by means of the environment» and "the environment involves a personal sharing in common experiences» (pp. 24, 90). The third assumption is the idea that the educational context organization has observable and significant consequences on the attitudes and behaviors of those who experience it. As Piaget (1932) said, «External constraint does not destroy egocentrism. It covers and conceals when it does not actually strengthen it» (p. 70). According to his theory, for the formation of the moral sense, it is essential that the educational context allows students to reflect on the meaning of rules and to participate, in collaboration with others, in their definition and adaptation to the experience.

For the definition of leadership, we referred to the Social Change Model of Leadership (SCML), in which leadership is considered to be an inclusive process, not dependent on the assumption of a formal role. It is a valuebased and improvement-oriented process, which «facilitate(s) positive social change at the institution or in the community» (HERI, 1996). This definition of leadership is based on theories concerning the cognitive development of post-secondary students (Student Development Theory) and the development of student leadership attitudes (Student Leadership). These theories are the Relational Leadership Model (Komives et al., 1998 and 2007), the Social Change Model of Leadership Development (HERI, 1996), the Servant Leadership Model (Greenleaf, 1977) and the Leadership Challenge Model (Kouzes \& Posner, 2002). 


\section{Methodology AND INSTRUMENTS}

The survey was conducted on a sample population of 600 students and 231 Scouts, aged 15 and 16 years, enrolled in upper secondary schools (9th and 10th grades) in Rome. The selection of the type of public secondary schools was based on a previous study on 1000 Scouts of the Lazio Region (Lucisano \& du Mérac, 2014). To have two comparable groups, we chose the same type of school in which the Scouts were enrolled.

The choice of the subject age is consistent with theories that identify adolescence as a phase of identity formation (Erikson, 1968; Marcia, 1980; Palmonari, 2001) and development of a personal value system through the formation of a more acute social conscience (Havighurst, 1972; Kohlberg \& Hersh, 1977), and which consider adolescence as the best time for learning leadership (Gardner, 1987; Van Linden \& Fertman, 1998).

Two research instruments were used: the Responsible Leadership Scale (SRLS-R2) (Dugan, 2006; Dugan \& Komives, 2009), translated and used for the first time in Italy, and the Educational Context Perception Questionnaire (ECPQ) (du Mérac, 2013), inspired by the Culture Questionnaire dimensions of the Global Leadership and Organizational Behavior Effectiveness research (GLOBE) (House et al., 2004) and reworked to adapt it to the school context.

The Socially Responsible Leadership Scale refers to the theoretical model of the Social Change Model of Leadership (HERI, 1996), in which leadership is seen as an interactive process that includes both the leader and the other members of the group, is improvement-oriented and involves skills, attitudes and behaviors that can be learned (Rost, 1991). According to this theoretical framework, leadership is based on values that are considered essential for a democratic society. The task of the leader is to "facilitate positive social change at the institution or in the community» (HERI, 1996, p. 19). The dimensions are grouped into three categories: Group Values (GV) (scales 1, 2,3) Individual Values (IV) (scales 4, 5, 6) and Social or Community Values (SV) (scale 7).

The SRLS-R2 scales are:

1. Collaboration, the ability to actively participate in common activities. The scale contains 8 items and has a Cronbach's Alpha of .75.

2. Common purpose, the ability to direct activities towards common goals and to participate in their definitions. The scale contains 9 items and has a Cronbach's Alpha of .81.

3. Controversy with civility, the ability to disagree with someone and, at the same time, respect his opinions, and see conflict as an opportunity for dialogue. The scale consists of 7 items and its Cronbach's Alpha is .070 . 
4. Consciousness of Self, the awareness of one's own personality and capacity for introspection. The scale contains 8 items and has a Cronbach's Alpha of .73.

5. Congruence, the authenticity and coherence between one's values, beliefs and behavior. The scale consists of 6 items and its Cronbach's Alpha is low (.59).

6. Commitment, reliability and ability to keep one's commitments. The scale contains 6 items and has a Cronbach's Alpha of .76.

7. Citizenship, the awareness of one's own responsibility and the action of doing something to improve the situation in one's community. The scale consists of 7 items. Its Cronbach's Alpha is .81.

8. Change or Courage through Change, the adaptability and ability to see things from a new point of view. The scale contains 9 items and its Alpha is .70.

A scale was built to measure the aged-related Leadership Capabilities (LC) (Halpin, 1954; Pollo, 1988) which relate to the ability to act as a leader. This scale considers three aspects considered essential for the assumption of a leadership role:

1. Capacity of Organization, which relates to the ability to organize the work of others.

2. Capacity of Motivation, which is the ability to promote, encourage and motivate others.

3. Accountability, which is the capacity to take on responsibilities.

The scale contains 10 items and its Alpha is .75.

The ECPQ was constructed to observe the impact of some aspects of the educational context in providing opportunities for leadership development.

The scales are the following:

1. Openness (Op), understood as the willingness to welcome and stimulate the adolescents' interests. The scale consists of 5 items and its Cronbach's Alfa is .70.

2. Horizontality of Relationships (HR), when the decisions are made not only by teachers, but also by students who share their responsibilities. The scale consists of 5 items and its Cronbach's Alpha is .72.

3. Affiliation (Aff), related to the group cohesiveness and the feeling among members that they are part of it. The scale contains 3 items and its Cronbach's Alpha is .80 .

4. Mutual Recognition (MR), the relationship of mutual trust and pride between the educators and the adolescents. The scale includes 5 items, its Cronbach's Alpha is .86 .

5. Fairness of Proceedings (FP), the mode of interaction and assessment, which does not depend on gender or sympathies of the educator. The scale consists of 6 items. Its Cronbach's Alpha is .68. 
6. Pleasantness of the Ambiance (PA), the absence of bullying and the perception of a nice relationship between the members of the group. The scale contains 6 items and its Cronbach's Alpha is .78.

\section{RESUlTS}

The main differences between the Scouting and educational environments, as related to attitudes of leadership and context perception, confirm the hypothesis that a model of active learning (Dewey, 1916 and 1938) contributes to developing responsible leadership attitudes.

The results indicate statistically significant differences in favor of the Scouts, with regard to leadership attitudes and capacities. At the same time, these indicate that the Scouts' perception of the educational context is significantly different and more positive (du Mérac, 2014a).

It is important to point out that the organizational model and the relational modalities are significantly different within a classroom and a Scouting group. For example, in Scouting the work evaluation is usually collective and a single activity can last for several days, while schools conduct individual assessments and a work group in it is generally spread over time. Furthermore, when the students and the Scouts say they have group activities, these do not have the same characteristics and thus the same impact on their attitudes. In fact, the ECPQ dimensions have a greater impact on leadership when these are related to the Scouting context (du Mérac, 2014b).

In this article, besides the descriptive statistics and reliability of the variables, I chose to present the findings related to the impact of the ECPQ scales on the Leadership scales.

\subsection{Descriptive statistics}

Descriptive statistics and the reliability of the variables included in the study are reported in Table 1. As can be observed, all self-reporting measures have acceptable-to-high levels of internal consistency.

Table 2 provides the intercorrelations among the study variables. The ECPQ scales and Leadership scales are positively intercorrelated to each other and also correlated between them. However, ECPQ scales and Individual Values (IV), as ECPQ scales and Change (Ch), are weakly correlated between them. 
Table 1. - Descriptive statistics.

\begin{tabular}{|c|c|c|c|c|c|c|}
\hline \multirow{2}{*}{ SCALES } & \multirow{2}{*}{ NR. OF ITEMS } & \multirow{2}{*}{ RELIABILITY } & \multicolumn{2}{|c|}{ Students } & \multicolumn{2}{|c|}{ Scouts } \\
\hline & & & MEAn & SD & MEAN & SD \\
\hline Op & 5 & .70 & 2.75 & .73 & 3.62 & .62 \\
\hline HR & 5 & .72 & 2.99 & .80 & 4.08 & .66 \\
\hline MR & 5 & .86 & 2.87 & .89 & 4.12 & .70 \\
\hline Aff & 3 & .80 & 2.85 & 1.02 & 4.15 & .77 \\
\hline $\mathrm{PA}$ & 6 & .78 & 3.42 & .86 & 4.24 & .68 \\
\hline $\mathrm{FP}$ & 6 & .68 & 3.52 & .74 & 4.23 & .68 \\
\hline SV & 7 & .81 & 3.52 & .72 & 4.02 & .56 \\
\hline LC & 10 & .75 & 3.46 & .66 & 3.96 & .58 \\
\hline IV & 20 & .81 & 3.87 & .52 & 4.00 & .47 \\
\hline GV & 23 & .89 & 3.64 & .57 & 4.09 & .39 \\
\hline
\end{tabular}

Table 2. - Correlations among variables.

\begin{tabular}{|c|c|c|c|c|c|c|c|c|c|c|}
\hline \multirow{2}{*}{ Scales } & \multicolumn{6}{|c|}{ ECPQ SCALES } & \multicolumn{4}{|c|}{ LEADERSHIP SCALES } \\
\hline & Op & HR & MR & Aff & $\mathrm{PA}$ & $\mathrm{FP}$ & SV & LC & IV & GV \\
\hline Op & 1 & & & & & & & & & \\
\hline $\mathrm{HR}$ & $.72^{* *}$ & 1 & & & & & & & & \\
\hline MR & $.68^{* *}$ & $.75^{* *}$ & 1 & & & & & & & \\
\hline Aff & $.61^{* *}$ & $.60^{* *}$ & $.63^{* *}$ & 1 & & & & & & \\
\hline PA & $.52^{* *}$ & $.54^{* *}$ & $.60^{* *}$ & $.73^{* *}$ & 1 & & & & & \\
\hline $\mathrm{FP}$ & $.52^{* *}$ & $.57^{* *}$ & $.62^{* *}$ & $.56^{* *}$ & $.65^{* *}$ & 1 & & & & \\
\hline SV & $.39^{* *}$ & $.36^{* *}$ & $.40^{* *}$ & $.38^{* *}$ & $.38^{* *}$ & $.33^{* *}$ & 1 & & & \\
\hline $\mathrm{LC}$ & $.42^{* *}$ & $.39^{* *}$ & $.44^{* *}$ & $.39^{* *}$ & $.40^{* *}$ & $.37^{* *}$ & $.59^{* *}$ & 1 & & \\
\hline IV & $.22^{* *}$ & $.14^{* *}$ & $.18^{* *}$ & $.22^{* *}$ & $.22^{* *}$ & $.19^{* *}$ & $.47^{* *}$ & $.41^{* *}$ & 1 & \\
\hline GV & $.48^{* *}$ & $.42^{* *}$ & $.49^{* *}$ & $.51^{* *}$ & $.51^{* *}$ & $.47^{* *}$ & $.74^{* *}$ & $.72^{* *}$ & $.54^{* *}$ & 1 \\
\hline
\end{tabular}

** Correlation is significant at the 0.01 level (2-tailed). 


\subsection{Impact of the educational context on leadership attitudes}

The perception of the educational context has a significant impact on the Group Values, Social Values and Leadership Capabilities (Table 3). However, the ECPQ scales have a low impact on the Individual Values. The analysis examined the pathways through which the ECPQ dimensions might be related to the mediating variable (subject: students and Scouts) and the outcomes (Leadership Capacities, Individual Values, Group Values and Social Values).

Findings include the following:

- Greater Openness is associated with Leadership Capacities, Group and Social Values for the students and with Individual Values for the Scouts.

- Greater Horizontality of the relationships is not associated with anything for the students. However, it is associated with Leadership Capacities, Group and Social Calues for the Scouts.

- Greater Mutual Recognition is associated for the students with Leadership Capacities and for the Scouts with Leadership Capacities, Group and Social Values.

- Better Affiliation is not related to anything for the students, but is associated with Group Values for the Scouts.

- Greater Pleasantness of the ambiance is related to higher Leadership Capacities and Group Values for the students and to Social Values for the Scouts.

- Greater Fairness of proceedings is associated with Group Values for the students. However, no relations were observed between this variable and the leadership attitudes for the Scouts.

The model (Figure 1) demonstrates an excellent fit to the data $\left(\chi^{2}(60)=\right.$ $1563.72, p<0.001, \mathrm{CFI}=1, \mathrm{TLI}=1, \mathrm{SRMR}=0.00, \mathrm{RMSEA}=0.00)$.

The Scouting context has more impact on the leadership dimension than the school context. At school, the ECPQ dimensions which have a greater impact on the leadership attitudes are Openness and Pleasantness of the ambiance and, to a lesser extent, Mutual Recognition and Impartiality. However, for Scouts, the ECPQ dimensions most relevant to leadership development are Horizontal Relationships, Mutual Recognition and Affiliation, which are the aspects of the context related to the relationships between the group members. The dimension of Openness, which does not refer to the group interactions, appears to have a significant impact on the Scout Individual Values. However, at school, no ECPQ dimension affects the student Individual Values. Therefore, we observe how the lack of interaction and group life within the class prevents the effect of the ECPQ scales that measure these aspects of the context, on the leadership dimensions. It makes sense that the Social and Group Value scores grow according to the quality of the group interactions and it is actually what happens in Scouting within our sample. 


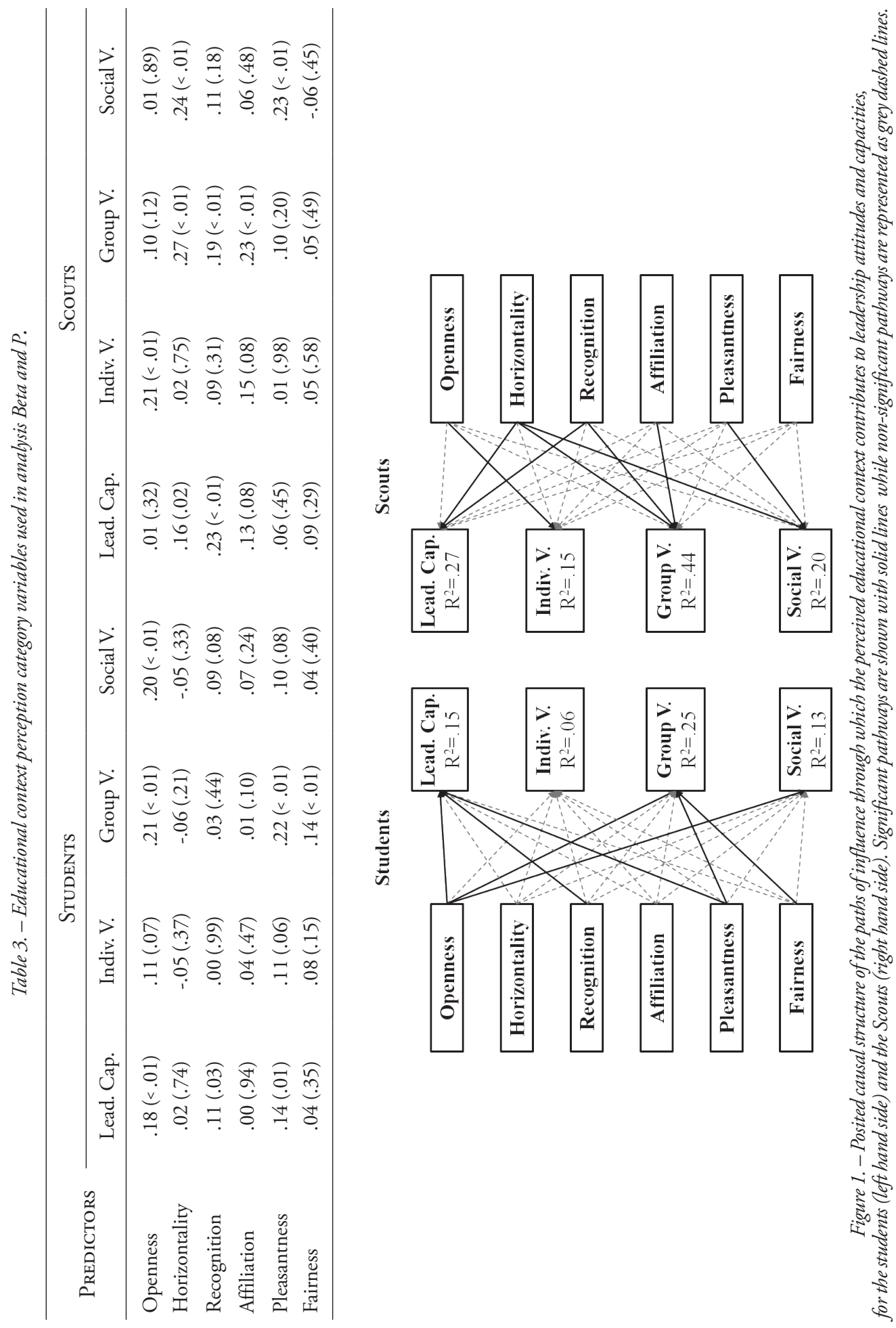


In fact, only through a group culture that provides the opportunity to participate and engage in joint activities it is possible to learn to collaborate, define common goals, respect differences, listen to others and take on responsibility.

Another variable that is very important in leadership development is having the opportunity to take responsibility. In the questionnaire, students were asked to indicate if they had some responsibility during their school experience and, if so, to describe it. Of the students, $81 \%$ answered negatively, and the remaining $19 \%$ reported having a responsibility generally only once, such as "raising money for a school trip», serving as their "class president in elementary school» or "helping a mate in trouble». However, even if the responsibilities given to the students are rare and minimal, the mere fact for them to have or having had one, has a significant impact on their values and leadership skills (du Mérac, 2014c). This result illustrates the potential impact of a school organization which allows each student to carry out a responsibility, even if small.

\subsection{The relationship among leadership variables}

To investigate postulated relationships among leadership variables, I used path-analysis. In this case, the students and Scouts were considered together, since the variables analyzed were the adolescent attitudes rather than the two different contexts.

The analysis examined the pathways through which the Individual Values (Commitment, Congruence and Consciousness of Self) might be related to the Group Values and the Group Values (Collaboration, Common purpose and Controversy with civility) might be related to Social Values, in accordance with the theoretical model proposed by Dugan et al. (2013). I chose to also investigate the impact of the Group Values on the dimensions of Change and Leadership Capabilities, within the theoretical framework in which life group experience and peer interaction play central roles and are considered to be essential to developing responsible leadership (HERI, 1996; Komives et al., 2006).

As Figure 2 indicates, greater Commitment and Congruence are associated with Group Values, while no relations are observed between Consciousness of Self and Group Values. The model provides a good fit to the data as revealed by all the fit indexes considered, $\chi^{2}(3)=54.338, p<0.001, \mathrm{CFI}=1$, $\mathrm{TLI}=1, \mathrm{SRMR}=0.00, \mathrm{RMSEA}=0.00$. 


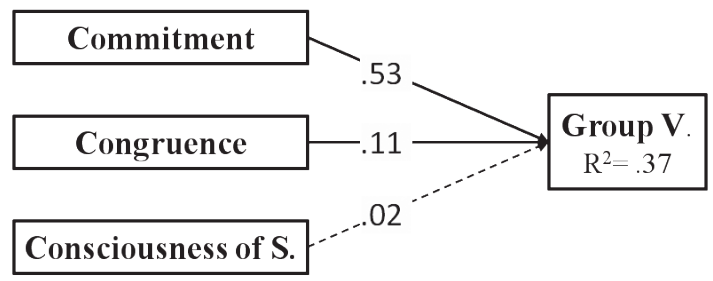

Figure 2. - Contribution of Commitment, Congruence and Consciousness of Self to the measurement of Group Values.

Significant pathways are shown with solid lines, while non-significant pathways are represented as dashed lines.

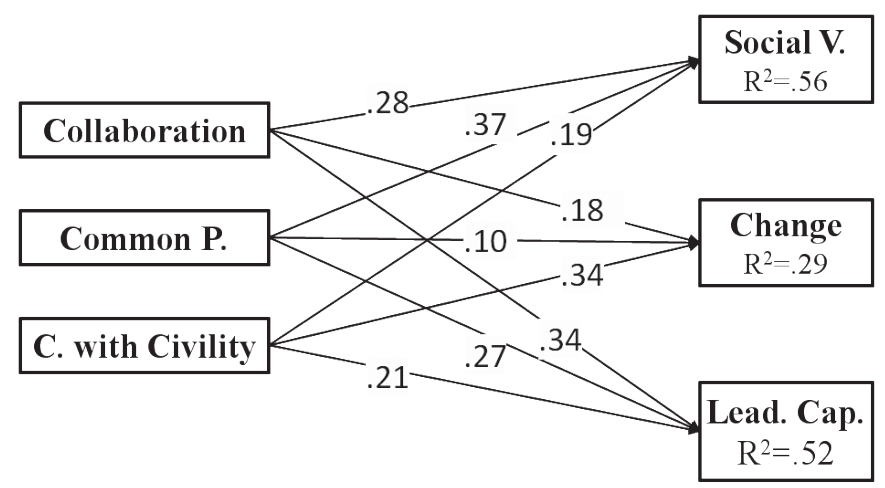

Figure 3. - Contribution of Collaboration, Common purpose and Controversy with civility to the measurement of Social Values,

Change and Leadership Capacities.

All the paths are significant at $p<0.05$. 
In Figure 3, results show that

- Greater Collaboration, Common purpose and Controversy are associated with Social Values.

- Better Collaboration and Controversy with civility are related to higher courage to make change (Change). However, Common purpose is not related to Change.

- Greater Collaboration, Common purpose and Controversy with civility are associated with Leadership Capabilities.

The model provides a good fit to the data as revealed by the various fit indices considered, $\chi^{2}(12)=212.629, p<0.001, \mathrm{CFI}=1, \mathrm{TLI}=1, \mathrm{SRMR}=$ 0.00, RMSEA $=0.00$.

The hypothetical model used by Dugan et al. and the author should not lead to the conclusion that there are no significant inverse impacts between the variables of leadership, but only unilateral relationships. We used pathanalysis to examine the models which are hypothesized to better fit the data, but it does not mean that there is no other significant relationship between leadership variables.

For example, otherness and interaction are essential to learn to know each other. However, it is also true that commitment with others to achieve an objective requires, at a minimum, to know oneself and have confidence in one's own abilities and potential.

\section{Conclusions}

To support what has been observed in the research data, it is worth recalling what Vygotsky said (1930-1931): «It is enough to change the social environment so that human behavior instantly changes. [...] The social environment is the real lever of the educational process» (p. 95). The fact that the activity, the organization and the quality of both have a significant impact on the development of attitudes such as responsibility, cooperation, self-awareness and leadership reverses the traditional role assigned to the educator. From being the protagonist of the knowledge, transmission becomes the promoterdesigner of the environment.

The idea that the core of education resides in the organization of the educational environment and activities is supported by Vygotsky, Piaget, Dewey, Montessori, Visalberghi and by all the advocates of an active learning model and representation of «school as a community in which they [students] can experience democratic participation and dialogue, sharing paths, initiatives and projects» (Moretti, 2011, p. 52). Dewey (1938) explains this idea, 
saying that "When it is said that the objective conditions are those which are within the power of the educator to regulate, it is meant, of course, that his ability to influence directly the experience of others and thereby the education they obtain places upon him the duty of determining that environment which will interact with the existing capacities and needs of those taught to create a worth-while experience» (ibid., p. 30).

In many schools, the quality of the interactions and the organization of the context are likely to contradict basic principles of democratic citizenship and active participation. Student engagement is necessary to allow «freedom to create and to construct, to wonder and to venture. Such freedom requires that the individual be active and responsible, not a slave or a well-fed cog in the machine» (Fromm, 1966, as cited in Freire, 1970, p. 68). It is clear that the mere transmission of moral principles is not sufficient to achieve the expected results at the individual and social level. Therefore, it seems necessary to rethink the overall organization of the school. The comparison with a different educational context indicates that there are more effective models, from which we can draw ideas and guidelines to help young people become active citizens and responsible leaders.

\section{REFERENCES}

Bossert, S., Dwyer, D., Rowan, B., \& Lee, G. (1982). The instructional management role of the principal. Educational Administration Quarterly, 18(3), 34-64.

Bourdieu, P. (1972). Esquisse d'une théorie de la pratique. Paris: Seuil, 2000.

Bruner, J. S. (1961). After Dewey what?. Saturday Review, 17(77), June.

Dewey, J.(1897). My pedagogic creed. New York: E.L. Kellogg \& Co. (trad. it., Firenze: La Nuova Italia, 1982).

Dewey, J. (1916). Democracy and education: An introduction to the philosophy of education. New York: The Macmillan Co. (trad. it., Firenze: La Nuova Italia, 1949).

Dewey, J. (1938). Experience and education. New York: Macmillan. Retrieved from: http://www.learnnc.org/lp/pages/4967.

Domenici, G., \& Moretti, G. (2011). Leadership educativa e autonomia scolastica: il governo dei processi formativi e gestionali nella scuola di oggi. Roma: Armando.

Dugan, J. P. (2006). SRLS-Rev2: Third revision of SRLS. College Park, MD: National Clearinghouse for Leadership Programs.

Dugan, J. P., Komives S. R., \& Associates (2009). Multi-institutional study of leadership 2009: Institutionalreports. College Park, MD: National Clearinghouse for Leadership Programs. 
Dugan, J. P., Kodama, C., Correia, B., \& Associates (2013). Multi-institutional study of leadership insight report: Leadership program delivery. College Park, MD: National Clearinghouse for Leadership Programs.

du Mérac, E. R. (2013). La misura degli atteggiamenti di leadership degli adolescenti in due contesti educativi: scuola e scautismo. Italian Society for Educational Research, 11, 95-111.

du Mérac, E. R. (2014a). What school could do to improve student value-based leadership? Journalof Authentic Leadership in Education, 3(4), 1-8.

du Mérac, E. R. (2014b). Misurare la leadership responsabile degli studenti e degli scout utilizzando modelli di regressione lineare. Journal of Educational, Cultural and Psychological Studies, 10, 511-535.

du Mérac, E. R. (2014c). Fiducia nei giovani: partiamo da piccole responsabilità in classe. Education 2.0: Educazione Didattica e Scuola. Retreived from: http:// www.educationduepuntozero.it/.

Durkheim, E. (1922). Éducation et sociologie. Paris: PUF, 2003.

Dwyer, D. (1986). Understanding the principal's contribution to instruction. Peabody Journal of Education, 63(1), 3-18.

Erikson, E. H. (1968). Identity, youth, and crisis. New York: Norton.

European Commission (2010). EUROPE 2020: A strategy for smart, sustainable and inclusive growth. Bruxelles: European Commission.

Freire, P. (1970). Pedagogy of the oppressed (30th anniversary ed.). New York: Continuum International Publishing, 2005.

Gardner, J. W. (1987). Leadership development: Leadership papers. Washington, DC.: Independent Sector.

Glasman, N. (1984). Student achievement and the school principal. Educational Evaluation and Policy Analysis, 6(3), 283-296.

Greenleaf, K. R. (1977). Servant leadership. Mahwah, NJ: Paulist Press, 1995.

Grace, G. (1995). School leadership: Beyond education management. An essay in policy scholarship. London - Washington, DC: Falmer.

Hallinger, P., \& Murphy, J. (1985). Assessing the instructional leadership behavior of principals. Elementary School Journal, 86(2), 217-248.

Halpin, A. W. (1954). The leadership behavior and combat performance of airplane commanders. Journal of Abnormal and Social Psychology, 49, 19-22.

Harber, C. (2002). Education, democracy and poverty reduction in Africa. Comparative Education, 38(3), 267-276.

Havighurst, R. J. (1972). Developmental tasks and education. New York: McKay.

HERI - Higher Education Research Institute (1996). A social change model of leadership development: Guidebook (version III). Los Angeles: Higher Education Research Institute, University of California. 
Hobbes, T. (1651). Leviathan or the matter, forme and power of a common wealth ecclesiastical and civil. London: Andrew Cooke.

House, R. J., Hanges, P. J., Javidan, M., Dorfman, P. W., \& Gupta, V. (2004). Culture, leadership, and organizations: The GLOBE study of 62 societies. Thousand Oaks, CA: Sage.

Kohlberg, L. (1984). Essays on moral development. San Francisco: Harper \& Row.

Kohlberg, L., \& Hersh, R. H. (1977). Moral development: A review of the theory. Theory into Practice, 16(2), 53-59.

Komives, S. R., Longerbeam, S., Owen, J. E., Mainella, F. C., \& Osteen, L. (2006). A leadership identity development model: Applications from a grounded theory. Journal of College Student Development, 47, 40-420.

Komives, S. R., Lucas, N., \& McMahon, T. R. (1998). Exploring leadership: For college students who want to make a difference. San Francisco: Jossey-Bass, 2007.

Kouzes, J. M., \& Posner, B. Z. (2002). The leadership challenge (3rd ed.). San Francisco: Jossey Bass.

Leithwood, K., Begley, P., \& Cousins, B. (1990). The nature, causes and consequences of principals' practices: An agenda for future research. Journal of Educational Administration, 28(4), 5-31.

Leithwood, K., \& Montgomery, D. (1982). The role of the elementary principal in program improvement. Review of Educational Research, 52(3), 309-339.

Loughran, J., \& Russell, T. (1997). Meeting student teachers on their own terms: Experience precedes understanding. In V. Richardson, Constructivist teacher education: Building new understandings (pp. 164-181). London: Falmer.

Lucisano, P., \& du Mérac, E. R. (2014). Le attese degli educatori per lo sviluppo della leadership e le risposte dei ragazzi scout di branca Guide/Esploratori dell'AGESCI. Orientamenti Pedagogici, 61(3), 633-662.

Makarenko, A. S. (1933-1935). Pedagogičeskaja poema (trad. it., Roma: Editori Riuniti, 1976).

Marcia, J. E. (1980). Identity in adolescence. In J. Adelson, The handbook of adolescent psychology. New York: Wiley.

Moretti, G. (2011). Dirigenza scolastica e competenze di leadership. In G. Domenici \& G. Moretti (a cura di), Leadership educativa e autonomia scolastica. Il governo dei processi formativi e gestionali nella scuola di oggi, Vol. 1 (pp. 31-67). Roma: Armando.

OECD (2004). Learning for tomorrow's world. First results from PISA 2003. Paris: OECD.

OECD (2012). Education at a glance 2012: OECD indicators. Paris: OECD.

Palmonari, A. (2001). Gli adolescenti. Né adulti, né bambini, alla ricerca della propria identità. Bologna: il Mulino.

Parsons, T. (1951). The social system. London: Routledge \& Kegan Paul. 
Piaget, J. (1932). Le jugement moral chez l'enfant. Paris: PUF, 2000.

Pollo, M. (1988). Il gruppo come luogo di comunicazione educativa. Torino - Leumann: LDC.

Rost, J. C. (1991). Leadership for the twenty-first century. Westport, CT: Praeger.

Schulz, W., \& Sibberns, H. (Eds.). (2004). IEA civic education study technical report. Amsterdam: IEA.

Skinner, J., Lizzio, A., \& Dempster, N. (2010). International handbook on leadership for learning. Dordrecht: Springer.

UNESCO (2005). Education for all: The quality imperative. EFA global monitoring report. Paris: UNESCO.

van de Grift, W. (1990). Educational leadership and academic achievement in elementary education. School Effectiveness and School Improvement, 1(3), 26-40.

Van Linden, J. A., \& Fertman, C. I. (1998). Youth leadership. A guide to understanding leadership development in adolescents. San Francisco: Jossey-Bass.

Vygotsky, L. S. (1930-1931). Istorija razvitija vyssih psihiceskih funktcij. Moskva: Accademia delle Scienze Pedagogiche della RSFSR (trad. it., Firenze: Giunti, 1974).

Woods, P. A. (2005). Democratic leadership in education. London: Paul Chapman.

WHO - World Health Organization (1993). Life skills education in schools. Genève: Division of Metal Health and Prevention of Substance Abuse.

WOSM - World Organization Scout Movement (2011). Constitution of W.O.S.M. Scout.org. Retrieved (01/07/2013) from: http://scout.org/sites/default/files/ library_files/WOSM_Constitution_EN.pdf.

\section{Riassunto}

L'obiettivo di questa ricerca è quello di analizzare l'impatto del contesto scolastico, rispetto a quello dell'ambiente scout, sugli atteggiamenti di leadership degli adolescenti. Al fine di esaminare come, e in quale misura, questi due ambienti educativi incidono sullo sviluppo della leadership, abbiamo utilizzato due strumenti: il "Questionario di Percezione del Contesto Educativo" (ECPQ) per l'analisi della percezione degli adolescenti del loro contesto educativo, e la «Socially Responsible Leadership Scale» (SRLS) per la misura dei Valori Individuali, di Gruppo e Sociali dei giovani; a queste due scale abbiamo aggiunto una dimensione di Capacità di Leadership. Lo studio è stato condotto sulle opinioni di un campione composto da 600 studenti e 231 scout iscritti alla scuola secondaria superiore di Roma. È stata utilizzata la "path-analysis» al fine sia di analizzare gli effetti, per gli studenti e gli scout, delle dimensioni dell'ECPQ sugli atteggiamenti e sulla capacità di leadership; sia di studiare le relazioni tra le variabili di leadership. I risultati hanno rivelato effetti diversificati, per gli studenti e per gli Scout a proposito della percezione del rilievo del 
contesto educativo sulle loro attitudini e capacità di leadership. Ė stato inoltre osservato un impatto significativo dei Valori Individuali sui Valori di Gruppo e un impatto significativo dei valori di Gruppo sui Valori Sociali e sulle Capacità di Leadership.

Parole chiave: Adolescenti, Leadership basata sui valori, Questionario di Percezione del Contesto Educativo (ECPQ), Scoutismo, Scuola secondaria, Social Change Model (SCM). 